\title{
Knowledge and Adoption of Recommended Cultivation Practices of Rabi Jowar among the Growers
}

\author{
R.D. Ahire, P.S. Kapse* and J.V. Ekale \\ Department of Extension Education, Vasantrao Naik Marathwada Krishi Vidyapeeth, \\ Parbhani-431 402 (M.S.), India \\ *Corresponding author
}

\section{Keywords}

Knowledge, Adoption, Rabi Jowar,

Recommended cultivation practices

\section{Article Info}

Accepted:

18 September 2018

Available Online:

10 October 2018

\section{A B S T R A C T}

The present study was conducted in Aurangabad and Beed district of Marathwada region to know the knowledge and adoption of recommended cultivation practices of Rabi Jowar among the growers. The Data was collected personally with the help of structured scheduled and analysed with the help of statistical methods. Data revealed that the majority of the respondents $(87.50 \%)$ had knowledge about the ploughing and harrowing operations whereas 62.50 per cent of them were aware about improved varieties of Rabi Jowar. Majority of them (91.67\%) were well known about the proper sowing time and 32.49 per cent of them had knowledge about recommended dose of fertilizers. It was depicted that 90.00 per cent of the respondents had knowledge about thinning, while 55.83 per cent of them had knowledge about various pests and diseases and 18.33 per cent of them were having knowledge about application of weedicides Atrazine. It was further observed that 80.83 per cent of them were well known about the protective irrigation. Cent per cent respondents were aware about the methods of harvesting. As regards to overall knowledge level, majority of them (54.17\%) had medium level of knowledge. In case of adoption of improved cultivation practices of Rabi Jowar by the respondents, it was found that about 87.50 per cent of them had fully adopted the practice of ploughing and harrowing, whereas, 66.67 per cent of them do not applied the manuring to the crop, while none of them had done the soil testing. It was also observed that 55.84 per cent respondents had adopted improved varieties, while 56.67 per cent of them had used recommended seed rate. It was also noticed that 35.00 per cent of them had done seed treatment. Majority of them had sown the crop during recommended sowing time. While 62.50 per cent of respondents had adopted the recommended spacing and 25.00 per cent of them had applied the recommended dose of chemical fertilizers to the crop. In case of plant protection, 37.50 per cent and 40.00 per cent of the respondents fully adopted plant protection measures for control of pest and disease, respectively. Only 8.33 per cent of them had sprayed weedicide Atrazine as per the recommendation. Most of the respondents (48.33\%) had medium level of adoption of recommended cultivation practices of Rabi Jowar, followed by 36.66 per cent and 15.00 per cent of the respondents were in low and high adoption level, respectively. 


\section{Introduction}

Sorghum (Sorghum bicolour (L.) Moench) popularly known as 'Jowar' is the most important food and fodder crop of dry land agriculture. This cereal crop is perennial in nature and possessing corn like leaves and bearing the grain in a compact cluster. Jowar is the fifth most important cereal crop in the world after wheat, rice, maize and barley. It is grown in the arid and semi-arid parts of the world, due to its feature of being extremely drought tolerant. Jowar is used for ethanol production, alcohol, starch production, production of adhesives and paper other than being used as food and feed.

The area under Rabi Jowar in Maharastra was around 26.08 lakh ha. during 2014-15 as compare to 19.81 lakh ha. in 2013-14. Whereas productivity had decreased to 584 $\mathrm{kg} . / \mathrm{ha}$. during 2014-15 from $893 \mathrm{~kg} . / \mathrm{ha}$. compare to 2013-14. In Marathwada region of Maharashtra state, jowar occupies 8.28 lakh ha, in 2014-15 compared to 7.46 lakh ha. in the year 2013-14 and the productivity was 452 $\mathrm{kg} / \mathrm{ha}$. in year 2014-15, whereas it was 1047 kg. / ha. in the year 2013-14.

Keeping in view the instability in yield and importance of jowar under climate change, the study was conducted to know the knowledge and adoption of recommended cultivation practices of Rabi Jowar among the growers in the Marathwada region with following objectives;

\section{Objectives}

To study the knowledge about recommended cultivation practices of Rabi Jowar by the respondents.

To study the adoption of recommended cultivation practices of Rabi Jowar by the respondents.

\section{Materials and Methods}

The present study was undertaken in the purposively selected Aurangabad and Beed district as these districts have maximum area under jowar cultivation in Marathwada region. From each district two talukas were selected and three villages from each talukas were selected purposively (i.e. total 12 villages were randomly selected). From each village ten farmers were selected randomly thus total samples were 120 respondents. The Data was collected personally with the help of structured scheduled. The data was analysed with the help of frequency, percentage, mean and standard deviation.

\section{Results and Discussion}

Knowledge of the growers about recommended cultivation practices of $\mathbf{R a b i}$ Jowar

The knowledge of the respondents about recommended cultivation practices of Rabi Jowar is presented in Table 1 .

\section{Preparatory tillage}

The majority of the respondents $(87.50 \%)$ had knowledge about the ploughing and harrowing operations, while 76.67 per cent of the respondents had knowledge about application of manuring for the crop. Whereas 66.67 per cent respondents were have knowledge about the suitable soil for the cultivation of Rabi Jowar. Only 10.00 per cent of them had knowledge about soil testing.

\section{Seed and seed treatment}

Regarding seed and sowing practices, 62.50 per cent of the respondents were aware about improved varieties of Rabi Jowar. Whereas more than half of the respondents $(58.33 \%)$ were knew about proper seed rate and seed 
treatment with thiram or 300 mesh fine sulphur $(4 \mathrm{gm} / \mathrm{kg}$.) was known by 25.00 per cent of the respondents.

\section{Sowing}

Majority of them (91.67\%) were well known about the proper sowing time, while 79.17 per cent of them had knowledge about recommended spacing of sowing (i.e. $45 \times 15$ $\mathrm{cm})$.

\section{Chemical Fertilizer}

It was revealed that 32.49 per cent of the respondents had knowledge about recommended dose of fertilizers (i.e. 80:40:40 $\mathrm{kg} /$ ha NPK), while 29.16 per cent of the respondents had knowledge about the application of nitrogenous fertilizer in spilt doses.

\section{Intercultural operations}

It was depicted that 90.00 per cent of the respondents had knowledge about thinning. Whereas, 25.00 per cent of them had knowledge about the weeding and hoeing operations as per the recommendation.

\section{Plant protection}

As regarding plant protection practices, 55.83 per cent of the respondents had knowledge about various pests and diseases of Rabi Jowar, whereas 50.00 per cent of them had knowledge about control measures of pest and diseases.

\section{Use of weedicides}

It was noticed that about 18.33 per cent of the respondents were having knowledge about application of weedicides Atrazine. Whereas, 16.66 per cent respondents had knowledge about proper concentration of Atrazine.

\section{Protective irrigation}

It was observed that 80.83 per cent of the respondents were well known about the protective irrigation in Rabi Jowar.

\section{Intercropping and mixed cropping}

It was clearly observed that 62.50 per cent of respondents were having knowledge about intercropping and mixed cropping in Rabi Jowar.

\section{Harvesting}

It was revealed that cent per cent respondents were aware about the methods of harvesting of Rabi Jowar. While 91.66 per cent of respondents had knowledge about maturity stage of Rabi Jowar.

\section{Overall knowledge}

It is portrayed from Table 2 that majority of the respondents $(54.17 \%)$ had medium level of knowledge.

Whereas 29.16 per cent and 16.67 per cent of them had low and high level of knowledge about recommended cultivation practices of Rabi Jowar.

\section{Adoption improved cultivation practices of Rabi Jowar by the respondents}

\section{Preparatory tillage}

It was found that about 87.50 per cent farmers had full adoption of ploughing and harrowing as per recommendation, while 65.00 per cent farmers had full adoption about suitable soil for cultivation of Rabi Jowar. Whereas, 66.67 per cent of the respondents do not applied the manuring to the crop, while none of the respondents had done the soil testing (Table $3)$. 
Table.1 Knowledge of the growers about recommended cultivation practices of Rabi Jowar

$(\mathrm{N}=120)$

\begin{tabular}{|c|c|c|c|}
\hline Sr. No. & Recommended cultivation practices of Rabi Jowar & Frequency & Per cent \\
\hline $\mathbf{A}$ & Preparatory tillage & & \\
\hline 1 & Soil testing & 12 & 10.00 \\
\hline 2 & Type of soil & 80 & 66.67 \\
\hline 3 & One ploughing \& Two harrowing & 105 & 87.50 \\
\hline 4 & Manuring (12-15 carts/ha.) & 92 & 76.67 \\
\hline B & Seed \& Seed treatment & & \\
\hline 1 & Improved varieties & 75 & 62.50 \\
\hline 2 & Seed rate $(10 \mathrm{~kg} / \mathrm{ha})$. & 70 & 58.33 \\
\hline 3 & $\begin{array}{l}\text { Seed treatment (Thiram / } 300 \text { mesh fine sulphar @ } 4 \\
\text { gm/kg seed) }\end{array}$ & 30 & 25.00 \\
\hline $\mathrm{C}$ & Sowing & & \\
\hline 1 & Sowing time (15 Sept. -15 Oct.) & 110 & 91.67 \\
\hline 2 & Spacing $(45 \times 15 \mathrm{~cm})$ & 95 & 79.17 \\
\hline D & Chemical Fertilizers & & \\
\hline 1 & $\begin{array}{l}\text { Recommended Dose of Fertilizers (80:40:40 kg/ha } \\
\text { NPK) }\end{array}$ & 39 & 32.49 \\
\hline 2 & Application of $\mathrm{N}$ as split dose & 35 & 29.16 \\
\hline $\mathbf{E}$ & Intercultural operations & & \\
\hline 1 & Thinning (10-15 days after sowing) & 55 & 45.00 \\
\hline 2 & Two Weeding \& Two Hoeing & 108 & 90.00 \\
\hline $\mathbf{F}$ & Plant protection & & \\
\hline 1 & Major pest and diseases of rabi jowar & 65 & 55.83 \\
\hline 2 & Control measures of pest $\&$ diseases & 60 & 50.00 \\
\hline $\mathbf{G}$ & Use of weedicides & & \\
\hline 1 & Application of weedicides (Atrazine) & 22 & 18.33 \\
\hline 2 & $\begin{array}{l}\text { Proper concentration of Atrazine ( } 1 \mathrm{~kg} \text { in } 1000 \text { liter } \\
\text { water for one hectare) }\end{array}$ & 19 & 16.66 \\
\hline $\mathbf{H}$ & Protective Irrigation & 97 & 80.83 \\
\hline I & Intercropping / Mixed cropping & 75 & 62.50 \\
\hline $\mathbf{J}$ & Harvesting & & \\
\hline 1 & At maturity stage & 110 & 91.66 \\
\hline 2 & Method of harvesting & 120 & 100.00 \\
\hline
\end{tabular}

Table.2 Overall knowledge of the growers about recommended cultivation practices of Rabi Jowar

$(\mathrm{N}=120)$

\begin{tabular}{|c|l|c|c|}
\hline Sr. No. & Overall Knowledge Level & Frequency & Percentage \\
\hline 1. & Low (Up to 10) & 35 & 29.16 \\
\hline 2. & Medium (11 to 19) & 65 & 54.16 \\
\hline 3. & High (20 \& above) & 20 & 16.66 \\
\hline
\end{tabular}


Table.3 Adoption of recommended cultivation practices of Rabi Jowar by the growers

\begin{tabular}{|c|c|c|c|c|c|c|c|}
\hline \multirow{2}{*}{$\begin{array}{l}\text { Sr. } \\
\text { No. }\end{array}$} & \multirow{2}{*}{$\begin{array}{l}\text { Recommended cultivation practices of } \\
\text { rabi jowar }\end{array}$} & \multicolumn{2}{|c|}{ Fully } & \multicolumn{2}{|c|}{ Partially } & \multicolumn{2}{|c|}{ No adoption } \\
\hline & & $\mathbf{F}$ & $\%$ & $\mathbf{F}$ & $\%$ & $\mathbf{F}$ & $\%$ \\
\hline $\mathbf{A}$ & Preparatory tillage & & & & & & \\
\hline 1 & Soil testing & 00 & 00.00 & 00 & 00.00 & 120 & 00.00 \\
\hline 2 & Type of soil (medium to black) & 78 & 65.00 & 42 & 35.00 & 00 & 00.00 \\
\hline 3 & One ploughing \& two harrowing & 105 & 87.50 & 10 & 08.33 & 05 & 04.17 \\
\hline 4 & Manuring ( 12 to 15 tones) & 30 & 25.00 & 10 & 08.33 & 80 & 66.67 \\
\hline $\mathbf{B}$ & Seed \& Seed treatment & & & & & & \\
\hline 1 & Use of improved varieties & 67 & 55.84 & 00 & 00.00 & 53 & 44.16 \\
\hline 2 & Seed rate $(10 \mathrm{~kg} / \mathrm{ha}$. $)$ & 68 & 56.67 & 52 & 43.33 & 00 & 00.00 \\
\hline 3 & $\begin{array}{l}\text { Seed treatment (Thiram / } 300 \text { mesh fine } \\
\text { sulphar @ } 4 \mathrm{gm} / \mathrm{kg} \text { seed) }\end{array}$ & 15 & 12.50 & 15 & 12.50 & 90 & 75.00 \\
\hline $\mathbf{C}$ & Sowing & & & & & & \\
\hline 1 & $\begin{array}{l}\text { Recommended sowing time (15 Sept. - } \\
15 \text { Oct.) }\end{array}$ & 110 & 91.67 & 10 & 08.33 & 00 & 00 \\
\hline 2 & Spacing $(45 \times 15 \mathrm{~cm})$ & 75 & 62.50 & 25 & 20.83 & 20 & 16.67 \\
\hline $\mathbf{D}$ & Chemical fertilizers & & & & & & \\
\hline 1 & $\begin{array}{l}\text { Recommended Dose of Fertilizers } \\
(80: 40: 40 \mathrm{~kg} / \mathrm{ha} \mathrm{NPK})\end{array}$ & 30 & 25.00 & 65 & 54.16 & 25 & 20.83 \\
\hline $\mathbf{E}$ & Intercultural operations & & & & & & \\
\hline 1 & Thinning $10-15$ days after sowing & 15 & 12.50 & 20 & 16.67 & 85 & 70.83 \\
\hline 2 & Two weeding (hand weeding) & 30 & 25.00 & 24 & 20.00 & 66 & 55.00 \\
\hline 3 & Two hoeing & 47 & 39.16 & 53 & 44.18 & 20 & 16.66 \\
\hline $\mathbf{F}$ & Plant protection & & & & & & \\
\hline 1 & Control measures of pest & 45 & 37.50 & 20 & 16.67 & 55 & 45.83 \\
\hline 2 & Control measures of diseases & 48 & 40.00 & 18 & 15.00 & 54 & 45.00 \\
\hline \multirow[t]{2}{*}{$\mathbf{G}$} & Use of weedicides & & & & & & \\
\hline & $\begin{array}{l}\text { Spraying of weedicides Atrazine ( } 1 \mathrm{~kg} \text { in } \\
1000 \text { liter water for one hectare) }\end{array}$ & 10 & 08.33 & 10 & 08.33 & 100 & 83.34 \\
\hline $\mathbf{H}$ & Protective irrigation & 16 & 13.34 & 20 & 16.66 & 84 & 70.00 \\
\hline I & Intercropping / Mixed Cropping & 67 & 55.84 & 33 & 27.50 & 20 & 16.67 \\
\hline $\mathbf{J}$ & Harvesting & & & & & & \\
\hline 1 & At maturity stage & 105 & 87.50 & 10 & 08.33 & 05 & 4.17 \\
\hline 2 & Proper method & 120 & 100.00 & 00 & 00.00 & 00 & 00.00 \\
\hline
\end{tabular}

Table.4 Overall of recommended cultivation practices of Rabi Jowar among the growers

\begin{tabular}{|c|l|c|c|}
\hline Sr. No. & Overall Adoption Category & Frequency & Percentage \\
\hline 1. & Low (Up to 14) & 44 & 36.66 \\
\hline 2. & Medium (15 to 28) & 58 & 48.33 \\
\hline 3. & High (29 \& above) & 18 & 15.00 \\
\hline
\end{tabular}

$(\mathrm{N}=120)$ 


\section{Seed and seed treatment}

As far as use of improved varieties is concerned, it was observed that 55.84 per cent of the respondents had adopted improved varieties. While 56.67 per cent of respondents had used recommended seed rate @ $10 \mathrm{Kg} /$ ha and 43.33 per cent of them used recommended seed rate partiality. It was also noticed that 35.00 per cent of them treated seed with Thiram / 300 mesh fine sulpha (4 $\mathrm{gm} / 10 \mathrm{~g}$.) as per recommendation.

\section{Sowing}

Majority of the respondents (91.67\%) had sown Rabi Jowar crop during recommended sowing time. As per as spacing is concern, 62.50 per cent of respondents had adopted the recommended spacing i.e. $45 \times 15 \mathrm{~cm}$.

\section{Chemical Fertilizers}

It was observed that 25.00 per cent of respondents had applied the recommended dose of chemical fertilizers to the crop. Whereas 54.16 per cent of them applied fertilizers dose partially to the crop.

\section{Intercultural operations}

In cases of intercultural operations, 70.83 per cent of the respondents do not adopted thinning practices in Rabi Jowar whereas 12.50 per cent respondents adopted thinning practices fully. While 25.00 per cent and 39.15 per cent of the respondents adopted two hand weeding and two hoeing operation fully as per recommendation, respectively.

\section{Plant protection}

In case of plant protection of Rabi Jowar, 37.50 per cent and 40.00 per cent of the respondents fully adopted plant protection measures for control of pest and disease, respectively. Whereas 45.83 per cent and 45.00 per cent of them do not adoption any control measures as per recommendation.

\section{Use of weedicide}

Regarding to use of weedicide, only 8.33 per cent of the respondents had sprayed weedicide Atrazine for Rabi Jowar as per the recommendation whereas 8.33 per cent of them had partially used the weedicide.

\section{Protective irrigation}

As regard to the application of protective irrigations, it was revealed that majority $(70.00 \%)$ respondents had not given protective irrigation due to non-availability of irrigation water. While only 13.34 per cent of them had irrigated their crop as per recommendation.

\section{Intercropping / mixed cropping}

As regard to the intercropping and mixed cropping, it was observed that 55.84 per cent of the respondents had fully adopted recommendations of intercropping and mixed cropping.

\section{Harvesting}

As regards harvesting at maturity stage, it was clear that 87.50 per cent of respondents had harvested their crop at proper maturity stage whereas cent per cent respondents had adopted the proper method of harvesting.

\section{Overall adoption}

Table 4 revealed that most of the respondents $(48.33 \%)$ had medium level of adoption of recommended cultivation practices of Rabi Jowar, followed by 36.66 per cent and 15.00 per cent of the respondents were in low and high adoption level, respectively. 
These findings are in line with findings of Sharma and Gupta (2010), Mane (2012) and Thorat (2013).

\section{References}

Mane, S.S. 2012. Knowledge and Adoption of Recommended Production Technology of Green Gram. M.Sc. (Agri.) thesis, VNMKV, Parbhani.
Sharma, L.K. and Vinod Gupta 2010. Knowledge and Constraints in Scientific Cultivation of Chilli among the Farmers. Rajasthan Journal of Extension Education, 17 \& 18: 60-64

Thorat, S.A. 2013. Knowledge and Adoption of Improved Package of Practices of Sunflower Growers. M.Sc. (Agri.) thesis, VNMKV, Parbhani.

\section{How to cite this article:}

Ahire, R.D., P.S. Kapse and Ekale, J.V. 2018. Knowledge and Adoption of Recommended Cultivation Practices of Rabi Jowar among the Growers. Int.J.Curr.Microbiol.App.Sci. 7(10): 2307-2313. doi: https://doi.org/10.20546/ijcmas.2018.710.267 